\title{
CYTOTOXICITY AND EXPRESSION STUDIES OF ANGIOGENESIS-PROMOTING GENES IN CANCER CELL LINES UNDER THE TREATMENT OF CANCER CANDIDATE DRUGS
}

\author{
SALAM ABBAS ${ }^{1 *}$, SUDHAKAR MALLA ${ }^{2}$ \\ ${ }^{1}$ Department of Nursing Technique, Kufa Technical Institute, 31003 AL_furatAL_Alawsat University, Kufa, Iraq. ${ }^{2}$ Department of \\ Biotechnology, Indian Academy Degree College, Bengaluru, Karnataka, India.
}

Received: 08 January 2019, Revised and Accepted: 27 March 2019

\section{ABSTRACT}

Objective: Human antigen R (HuR) is a member of the RNA-binding proteins which is a critical factor in mediating the proangiogenic factors resulting in angiogenesis among the tumors. During inflammation and anoxic conditions, cytokine interleukin-1 (IL-1) was found to activate the HuR which, in turn, aids in upregulation or downregulation of the hypoxia-inducible factors (HIF) $1 \alpha$. The present study was designed to study the correlative effect of the cancer drug docetaxel (Taxotere) on the expression levels of HuR and HIF1 $\alpha$ using HeLa cell lines.

Materials and Methods: The drug was tested for cytotoxicity among the cancer cell lines using the lactate dehydrogenase and 3-(4)5-Dimethylthiazol-zyl)-2, 5, biphenyl tetrazolium bromide assay. Gene expression and correlation were found by the real-time expression of the gene members under the treatment. The same study was also confirmed using the molecular docking tools to screen for the possible potential anticancer target.

Results: The drug was found to decrease the expression levels of the cytokine IL-1 along with the HuR proteins. This was also found to show a positive inhibition on the expression of HIF1 $\alpha$. The study was also confirmed using the molecular docking studies which are in accordance to the wet lab studies.

Conclusion: The present study confirmed that the two receptors might act as potential anticancer drug targets which might aid in designing more novel drugs.

Keywords: Human antigen R, Anticancer targets, Hypoxia-inducible factors $1 \alpha$, Docetaxel.

(C) 2019 The Authors. Published by Innovare Academic Sciences Pvt Ltd. This is an open access article under the CC BY license (http://creativecommons. org/licenses/by/4. 0/) DOI: http://dx.doi.org/10.22159/ajpcr.2019.v12i5.31929

\section{INTRODUCTION}

Cancer remains a major health problem in the world, both in developed and developing countries. The World Health Organization and World Bank estimate that 12 million people worldwide suffer from cancer annually and 7.6 million of them died [1]. The high incidence and mortality of cancer patients are currently due to low rate of the success of treatments. Various methods against cancer have been developed including surgery, radiation, immunotherapy, and chemotherapy. However, the success rate of the methods is still low due to its disadvantages [2]. This situation encourages the efforts to discover and develop novel anticancer drugs that more effective and sensitive without serious side effects [3]. Cancer cell proliferation occurs beyond normal limits, and it is uncontrolled. This is due to the disruption of cell cycle, the increase of angiogenesis, and suppression of apoptosis. Apoptosis is a form of cell death designed to eliminate unwanted host cells $[4,5]$. The process of apoptosis is programmed through a series of events involving a set of gene products. Apoptosis is responsible for physiological and pathological processes. In the pathological process, apoptosis plays a major role in tumor cell death [6].

Human antigen R (HuR), a ubiquitously expressed member of the embryonic lethal abnormal vision (ELAV) family of RNA-binding proteins, exhibits specific affinities for AU-rich elements-containing RNA sequences [7] in vitro which correlate with their in vivo decay rates, thereby implicating HuR in the proangiogenic factors mediated angiogenesis. Generally speaking, angiogenesis is initiated by hypoxic or inflammatory conditions $[8,9]$. Hypoxia and inflammation activate HuR function through modulation of HuR subcellular localization and RNA-binding activity [6]. Furthermore, another inflammation-related cytokine interleukin-1 [10] could also activate the function of HuR to stabilize a set of target mRNAs for the fulfillment of a certain process [11]. In turn, activated HuR stabilizes TNF $\alpha$ or promotes the translation of hypoxia-inducible factors (HIF) $1 \alpha$ through the ARE located in the 3 ' UTR, forming a positive feedback $[12,13]$.

Considering the multiple roles of HIF-1 in tumor progression and metastasis, there have been great interests in developing inhibitors targeting this pathway. It is clear that HIF-1 $\alpha$ regulation pathway is a highly complex network involving several signaling cascades and overlapping mechanisms, each of which could serve as a promising target or step to intervene selectively [14]. It is not surprising that most of the reported HIF- $1 \alpha$ inhibitors were originally discovered for targeting other endogenous molecules and later their HIF- $1 \alpha$ inhibitory activity was recognized through some empirical testing. For this reason, there are no specific HIF-1 $\alpha$ inhibitors [15] currently and developing specific HIF$1 \alpha$ inhibitors in hypoxic tumors represent a challenge. Taxotere is the trade name for docetaxel. In some cases, health-care professionals may use the trade name Taxotere when referring to the generic drug name docetaxel. Docetaxel is an anticancer ("antineoplastic" or "cytotoxic") chemotherapy drug [16]. It has been approved in the treatment of breast cancer, non-small cell lung cancer, advanced stomach cancer, head and neck cancer, and metastatic prostate cancer [17]. Currently it is being studied to treat small cell lung, ovarian, bladder, and pancreatic cancers, soft tissue sarcoma and melanoma [19].

In the present study we aimed to screen for the potency of the drug Docetaxel against the hypothetical drug targets for pancreatic cancer. The study was conducted on the HeLa cell lines by estimating the gene expression levels of the possible drug targets under the drug treatment. The study was also confirmed using the in silico studies.

\section{MATERIALS AND METHODS}

The cell culture medium (Dulbecco's Modified Eagle's medium [DMEM]), fetal bovine serum (FBS), trypsin-ethylenediaminetetraacetic 
acid (EDTA), penicillin and streptomycin were purchased from HiMedia labs. Human cervical carcinoma HeLa cells were obtained from Indian Academy degree college, Bangalore, India. The cell lines were cultured in the DMEM medium, supplemented with FBS (10\%) and streptomycin $(100 \mu \mathrm{g} / \mathrm{mL})$. The cells were grown in $\mathrm{CO}_{2}$ incubator (Memmert, Germany) at about $37^{\circ} \mathrm{C}$ with $90 \%$ humidity and $5 \% \mathrm{CO}_{2}$. Cells were subcultured when confluent using trypsin/EDTA. Docetaxel (Taxotere) CAS Number 114977-28-5 was purchased from Sigma-Aldrich. The drug was soluble in methanol and sued at varying concentrations for the study.

\section{Primers design}

Primer pairs were designed using Primer 3 software according to the protocol described by Sudhakar et al. [18] and were purchased from Sigma Aldrich. The specificity of the polymerase chain reaction (PCR) products and the primer pairs was checked in silico using BLAST (National Centre for Biotechnology Information) alignment tools.

3-(4)5-Dimethyl-thiazol-zyl)-2, 5, biphenyl tetrazolium bromide (MTT) assay

The current study was investigated to study the cytotoxic activity of the methanolic suspension of the selected drug on the HeLa using MTT assay [20]. The cells were treated with different concentrations $(10,20,40,60,80$, and $100 \mu \mathrm{g} / \mathrm{ml})$ of the drug suspension to estimate the percentage cytotoxicity and half maximal inhibitory concentration $\left(\mathrm{IC}_{50}\right)(50 \%$ growth inhibition). Colchicine $(2.5 \mathrm{nM})$ was used as positive control throughout the study. The cells were plated at a cell density of about 5000-8000 cells/well and seeded in 96-well plates (HiMedia). After $24 \mathrm{~h}$ of incubation in the incubator, the cells were treated with different concentrations of the drug suspension. First, well without treatment was maintained as control. Following treatment, the cells were added with $20 \mu \mathrm{L}$ of MTT solution $(5 \mathrm{mg} / \mathrm{mL}$ in phosphatebuffered saline [PBS]), and after incubation for $4-5 \mathrm{~h}$, the media were removed and the cells were washed thrice with PBS. The plate was then vibrated for about $15 \mathrm{~min}$ before measuring the absorbance at $570 \mathrm{~nm}$ in each well using an enzyme-linked immunosorbent assay plate reader (Genetix, Bengaluru). Cytotoxicity was expressed as a percentage of growth inhibition and the concentration needed to inhibit the cell growth by $50 \%\left(\mathrm{IC}_{50}\right)$ was calculated. Percentage growth inhibition was calculated using the formula (1-[Optical density (OD) of treated/OD of control] $) \times 100$. Each of the experiment was done using six replicates for each of the drug concentration and repeated in triplicates.

Lactate dehydrogenase (LDH) assay

Toxicity of the suspension was also assayed by estimating the concentration of the cytosolic enzyme LDH which is usually released into the media when the cell membrane gets damaged.[21] The cells were seeded according to the protocol as described in the previous section, and the drug suspensions at respective concentrations $(0.5$, $1,1.5,2,2.5$, and $3 \mu \mathrm{g} / \mathrm{ml}$ ) were added for treatment. Wells without treatment were served as control. Following incubation, after $24 \mathrm{~h}$, the contents from each well were removed and estimated for the release of LDH into the media. The cytotoxicity was measured using the plate reader (Genetix) at $540 \mathrm{~nm}$.

\section{RNA extraction}

The over confluent cell cultures (both treated 1.5 and $3 \mu \mathrm{g} / \mathrm{ml}$ and controls) were used in the extraction process. Total RNA was then extracted using an RNeasy Mini Kit (Qiagen 74104). The experiment was conducted based on the instructions mentioned in the kit.[22]
The trypsinized cells after suspending in $2 \mathrm{ml}$ of PBS were pelleted down by centrifuging at $6000 \mathrm{rpm}$ for $5 \mathrm{~min}$. The pellet obtained was

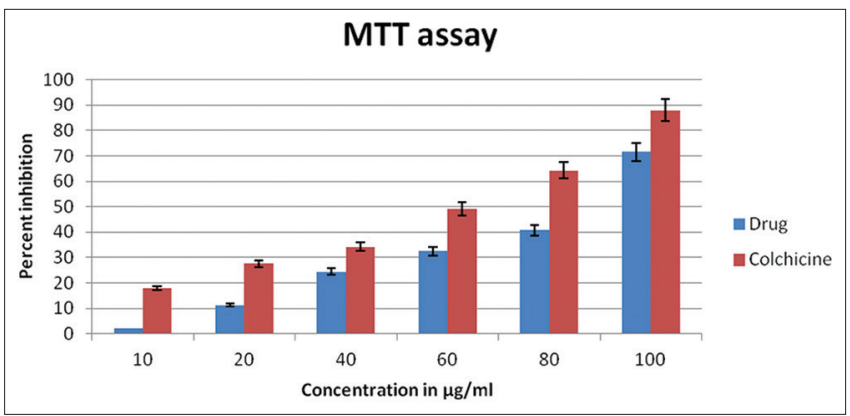

Fig. 1: The percent inhibition values in 3-(4)5-Dimethyl-thiazolzyl)-2, 5, biphenyl tetrazolium bromide assay. All the values were average of triplicates and the values are expressed as value \pm standard error. All the measurements were normalized to control $(0 \%)$

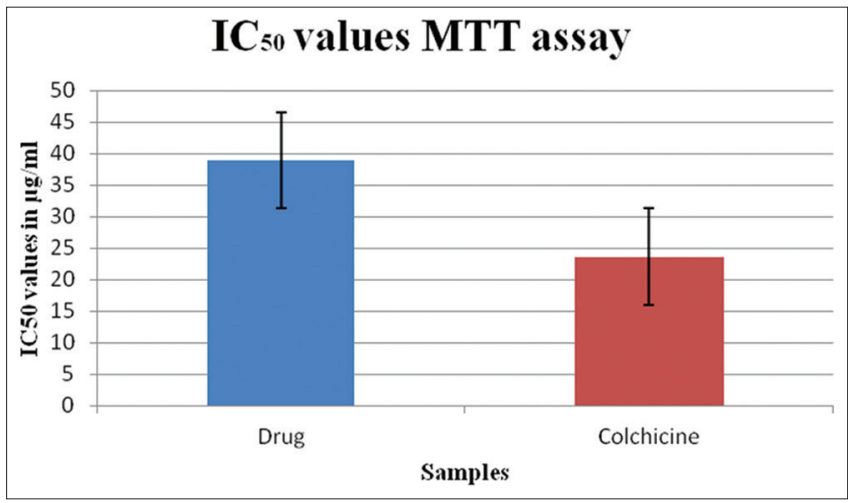

Fig. 2: The half maximal inhibitory concentration values in 3-(4)5-Dimethyl-thiazol-zyl)-2, 5, biphenyl tetrazolium bromide assay. All the values were average of triplicates and the values are expressed as value \pm standard error

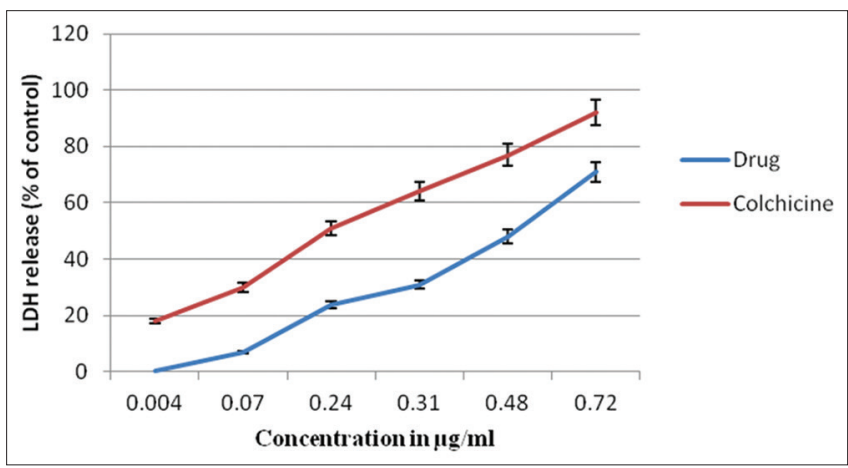

Fig. 3: The percentage of lactate dehydrogenase (LDH) released from HeLa cells following $24 \mathrm{~h}$ exposure in LDH assay. All the values were average of triplicates and the values are expressed as percentage control values \pm standard error. All the measurements were normalized to control $(0 \%)$

Table 1: The details of primers used in the RT-PCR

\begin{tabular}{llllll}
\hline Gene & & Sequence $\left(5^{\prime}\right.$-> $\mathbf{3}^{\prime}$ ) & Length & GC\% & Product \\
\hline HuR & FW & GAGGTAGGGACCACCAGGAT & 20 & 60.03 & 888 \\
& RV & ACTTGCTCTTTTCTCTTGGCAG & 23 & 59.68 & \\
HIF-1A & FW & TGACCTGCTTGGTGCTGATT & 20 & 59.89 & 208 \\
& RV & GCGCTGAATCTTTGCTATGG & 20 & 57.6 & \\
\hline
\end{tabular}

HuR: Human antigen R, HIF: Hypoxia-inducible factors, RT: Reverse transcription, PCR: Polymerase chain reaction, FW: Forward, RV: Reverse 
then resuspended in $560 \mu \mathrm{l}$ AVL buffer and $560 \mu \mathrm{l}$ chilled ethanol. The contents were mixed thoroughly and centrifuged again at $8000 \mathrm{rpm}$ for about 1 min to facilitate the RNA to bind to the column. The column was then washed with $700 \mu \mathrm{l}$ of wash buffer and centrifuged at $15 \mathrm{~s}$ followed by incubation with $60 \mu \mathrm{l}$ of AVE buffer. The RNA eluted was now collected in the $2 \mathrm{ml}$ of collection tubes and stored at $-20^{\circ} \mathrm{C}$. The RNA quality was checked by the ultraviolet spectrophotometer and used for complementary DNA (cDNA) synthesis.

\section{Reverse transcription (RT) PCR: cDNA synthesis}

The cDNA synthesis was carried using the RT PCR kit using SuperScript TMII Reverse Transcriptase, $200 \mathrm{U} / \mu \mathrm{l}$ (HiMedia). In brief, $2 \mu \mathrm{g}$ of the RNA obtained in the previous section was used as the starting reaction. The RNA concentration obtained was about $1.97 \mu \mathrm{g} / \mu \mathrm{l}$. Hence, about $1.12 \mu \mathrm{l}$ of the total RNA was used in the reaction. Random primers and
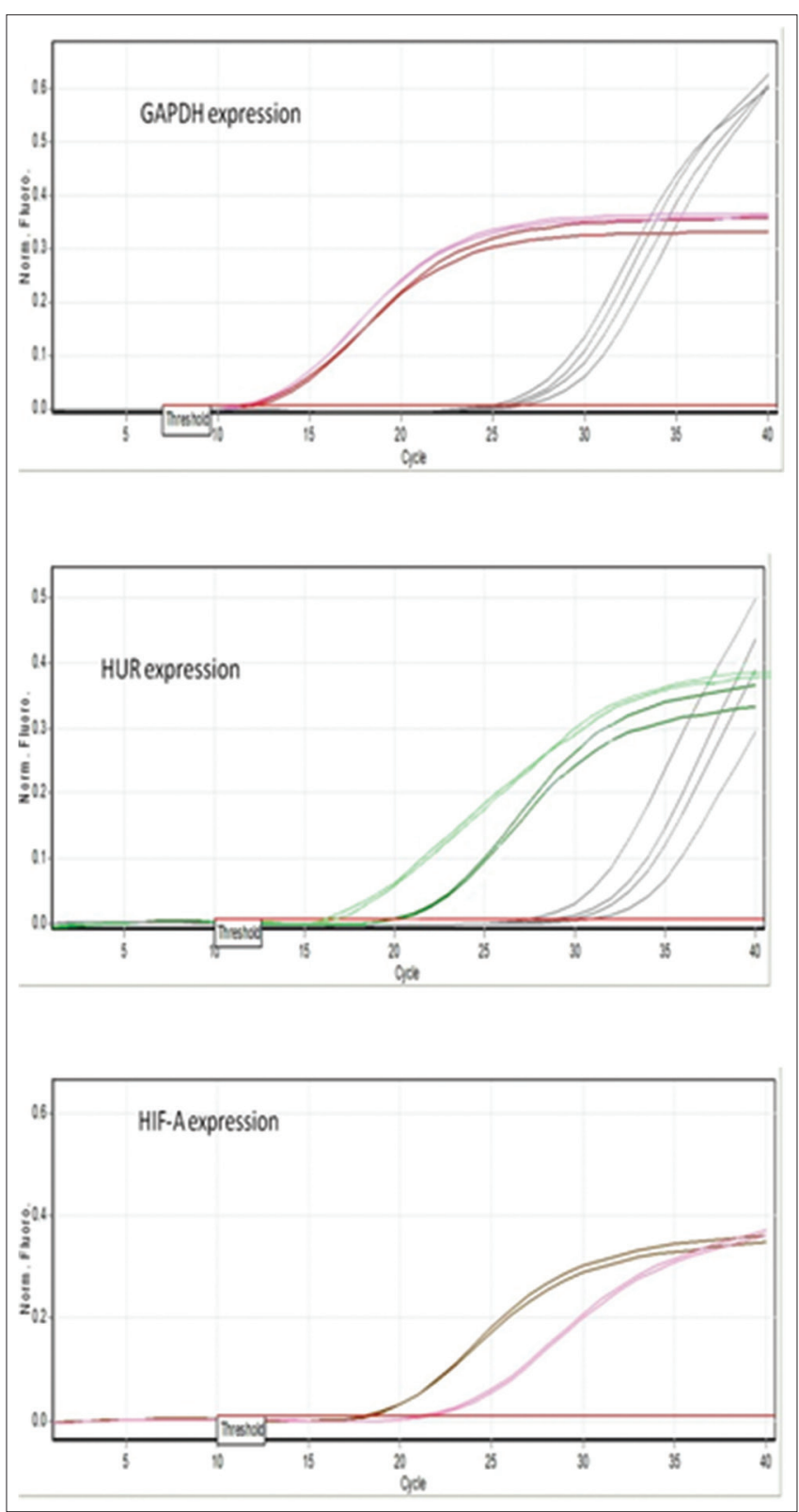

Fig. 4: Images of quantification curves of the expression of gene members. Left: Glyceraldehyde-3-phosphate dehydrogenase housekeeping gene; Middle: Human antigen R gene expression (dark line: Treatment and light line: Control); Right: Hypoxiainducible factor A gene expression (Dark line: Control and light line: Treatment). Ct values are average of duplicates
$1 \mu \mathrm{l}$ of RT enzyme were added mixed thoroughly, and the contents were incubated at $25^{\circ} \mathrm{C}$ for $10 \mathrm{~min}$. Followed by the incubation at $70^{\circ} \mathrm{C}$ for $45 \mathrm{~min}$, the cDNA obtained was then stored and used for real-time PCR analysis.

\section{Real-time PCR}

Primers for real time (Table 1) were designed using primer3 software and were purchased from Sigma-Aldrich. The real-time PCR assay was then performed according to Deepak et al. using the iQTM SYBR Green Supermix (HiMedia). The primers $(600 \mathrm{nM})$ and $1 \mu \mathrm{l}$ of the RT products were used in the PCR assay, and the reaction was done in a total volume of $12.5 \mu \mathrm{l}$. All the reactions were carried out in duplicates and also run in parallel with its respective negative control, to confirm the positive amplification.

\section{Expression of HuR and HIF1-A members in samples}

Real-time quantification was carried on the sample (both control and treatment) in the Corbett Research cycler (Bio-Rad). The HuR primers (HUR) (forward: 5' GGGGGCATTCTAAGTCCAGTGA 3' and reverse: 5' TATCCCGCTATCCC CCTACATTAT 3'; 509bp) and HIF1-A (HIFA) of about $600 \mathrm{nM}$ concentration were used for the amplification program. $1.1 \mu \mathrm{l}$ of the RNA products were initially used, and the program was run for about 40 cycles at $92^{\circ} \mathrm{C}$ for $50 \mathrm{~s}, 64^{\circ} \mathrm{C}$ for $40 \mathrm{~s}$, and with an elongation at $72^{\circ} \mathrm{C}$ for $60 \mathrm{~s}$. The housekeeping gene glyceraldehyde-3-phosphate dehydrogenase (GAPDH) (forward: 5' TGGAAAGCTGTGGCGTGAT 3' and reverse: 5' CCCTGTTGCTGTAGCCGTAT 3'; 395bp) was also amplified along with the respective gene of interest for a comparative analysis of the mRNA expression. The comparative analysis of the relative levels of mRNA of the test samples (including control) was quantified using ${ }^{\Delta \Delta} \mathrm{Ct}$ method. The $\mathrm{Ct}$ values obtained for the gene of interest were normalized to its housekeeping gene.

\section{Docking studies}

Software such as SWISH Model, swish PDB viewer, ACD ChemSketch, Rampage, Argus Lab 4.0.1, and PATCHDOCK were used in the docking studies. HUR and HIF1-A receptors were used in the present context, and a model study to dock or inhibit the receptors were aimed at. Humanlike antigen R and hypoxia-inducible factor 1 alpha (NC_000014.9) were taken from the National Center for Biotechnology Information Entrez database. Homology modeling was done using SWISH Model freeware and the best template was chosen for the docking study. The models selected were further analyzed on PatchDock for docking studies.

\section{RESULTS AND DISCUSSION}

\section{MTT assay}

All the measurements were normalized to control (without treatment) and were considered as $0 \%$. Our study confirmed that the treatment of the cells with the drug suspension at $10 \mu \mathrm{g} / \mathrm{mL}$ showed proliferation activity but was very negligible when compared to the positive control and was found to be dose dependent. The activity of the drug was also found to positive when compared to colchicine and negative control. These values indicate that the drug suspension was equally potent to

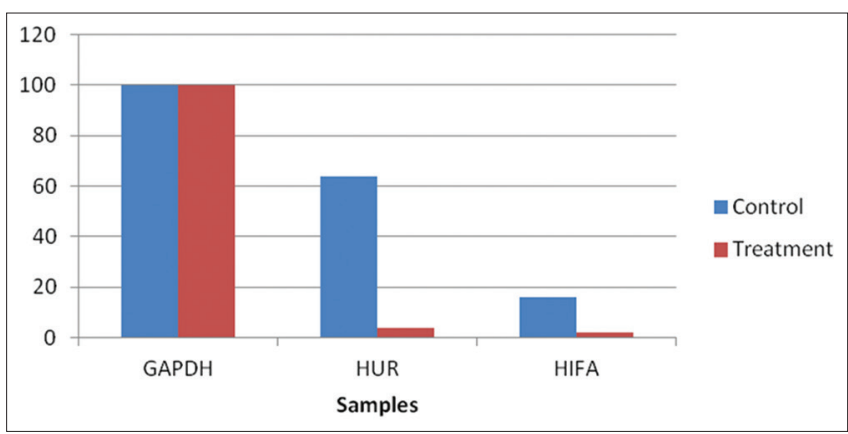

Fig. 5: The $2^{-\Delta \Delta \mathrm{Ct}}$ values for the gene members obtained from the real-time polymerase chain reaction. All the experiments were average of duplicates 


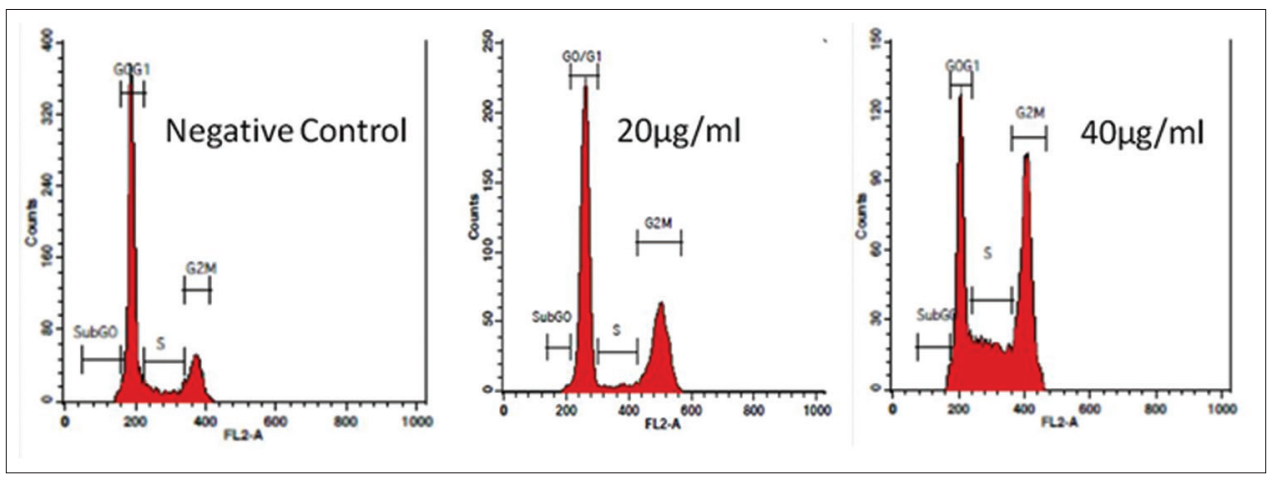

Fig. 6: The cell cycle analysis results. 1\% dimethyl sulfoxide was used as a negative control. All the values are average of triplicates

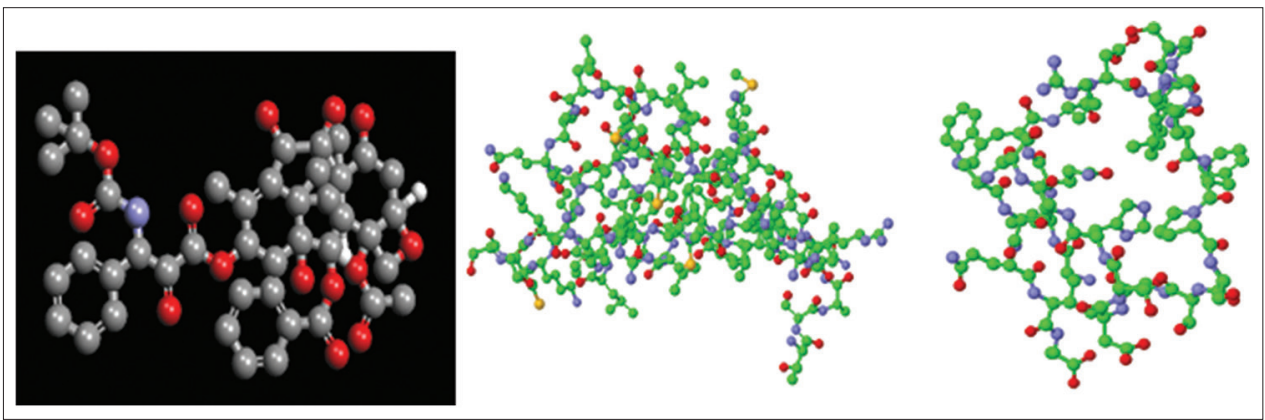

Fig. 7: Images of the drug and receptors. Images were as viewed from Arguslab. Left: Drug molecule; middle: Human antigen R 1 receptor; right: Hypoxia-inducible factors $1 \mathrm{~A}$ receptor

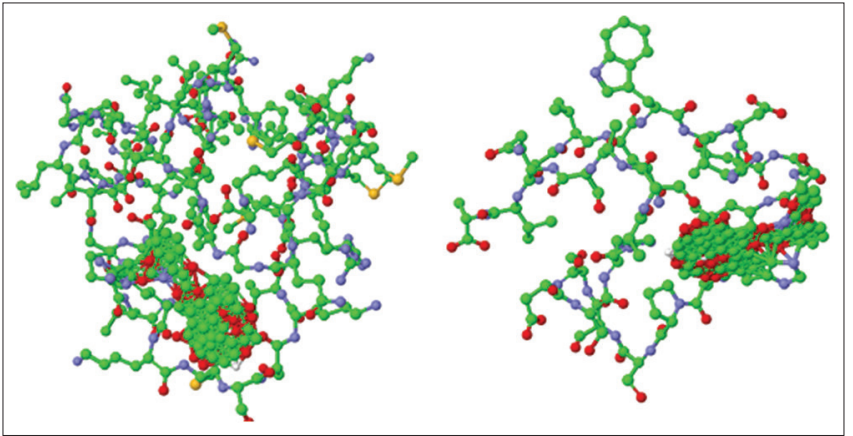

Fig. 8: Images of the solutions obtained from the PatchDock. Images were as viewed under Arguslab

positive control. The $\mathrm{IC}_{50}$ values were found to 38.8 and 23.56 for the drug and positive control, respectively (Fig. 1 and Fig. 2).

\section{LDH assay}

Drug-induced membrane damage on HeLa cell lines was assayed by LDH release. After incubation, the amount of LDH release was calculated in comparison to the negative control (OD 0.01). Our results reported that, relative to untreated cells, the release was found to be dose dependent and the results were in accordance to MTT assay (Fig. 3). At an initial concentration, the release was very negligible when compared to colchicine and negative control. After $24 \mathrm{~h}$ of incubation, the drug suspension showed a significant increase in the LDH release relative to the control after $1 \mu \mathrm{g} / \mathrm{ml}$. At a concentration of $3 \mu \mathrm{g} / \mathrm{ml}$, the percentage release was found to $71 \pm 19.4$ and $92 \pm 13.4 \%$ for drug and positive control, respectively $(\mathrm{p}<0.05)$.

\section{Expression of gene members}

All the results obtained are normalized to housekeeping gene (GAPDH), to reduce the differences, that usually occurs between the samples. The level of mRNA expression of each gene member (GAPDH, HUR, and
HIFA) was studied separately. The sample with the lower ${ }_{\Delta \Delta} \mathrm{Ct}$ values was taken as calibrator, and the remaining samples were relatively compared with that calibrator. The Ct values of the housekeeping gene, HUR, and HIFA were found to be 11, 21, and 18, respectively. Based on the $\mathrm{Ct}$ values, the $\mathrm{Ct}$ values of the samples (treatment with the drug) were normalized to the housekeeping gene (GAPDH). The GAPDH gene expression was considered as $100 \%$. From the studies and calculated $2^{-\Delta \Delta C t}$ values, it was observed that the HUR gene was under expressed when compared to the control and HIFA. Both HUR and HIFA were under expressed in the treatment than the control (Fig. 4 and Fig. 5). HUR gene was 64 times under expressed in the treatment and HIFA was 16 times under expressed on treatment.

\section{Cell cycle distribution}

Cell cycle distribution by fluorescence-activated cell sorting (FACS) analysis was done using HeLa cell lines to find out whether the drug suspension exerted any anticancerous effect by inducing the cell cycle arrest. The experiment was followed according to Kaur et al. In brief, approximately $1 \times 10^{6}$ cells (HeLa) were plated in a 6-well plate containing $2 \mathrm{ml}$ of complete DMEM. Following incubation for $24 \mathrm{~h}$, cells were treated with or without (control) drug suspension at varying concentrations of 20 and $40 \mu \mathrm{g} / \mathrm{ml} .20 \mu \mathrm{M}$ of colchicine was used as positive control and $1 \%$ dimethyl sulfoxide as negative control $(1 \%$ in DMEM media), the cells were collected and centrifuged at maximum speed of $5 \mathrm{~min}$ at RT, and the pellet was collected. The pellet was resuspended in $1 \times \mathrm{PBS}$ and fixed overnight at $4^{\circ} \mathrm{C}$ in a $2 \mathrm{ml}$ of fixing solution (20\% PBS in $70 \%$ ethanol). The cells were then pelleted by centrifuging at $4000 \mathrm{rpm}$ for $10 \mathrm{~min}$ (RT). The pellet was washed with cold $1 \times$ PBS and incubated for $15 \mathrm{~min}$ (RT) in $500 \mu \mathrm{l}$ of propidium iodide (PI) solution containing $0.05 \mathrm{mg} / \mathrm{ml} \mathrm{PI}$ and $0.05 \mathrm{mg} / \mathrm{ml} \mathrm{RNaseA} \mathrm{in} \mathrm{PBS.}$ The percentage of cells or viability in various stages of the cell cycle in both treatment and controls was determined using FACS Caliber (BD Biosciences, San Jose, CA).

\section{Cell cycle analysis}

Our results of cell cycle analysis by flow cytometry in case of HeLa cell lines indicate that the drug suspension has significantly arrested the 
G2M phase of cell cycle. The cell cycle arrest in G2M phase was found to be $33.82 \pm 0.05 \%$ and $42.86 \pm 0.03 \%$ at 20 and $40 \mu \mathrm{g} / \mathrm{ml}$, respectively, when compared to positive control $(80.83 \pm 0.02 \%)$. The arrest was found to be $11.45 \pm 0.33 \%$. The results confirm that the drug is a potent inhibitor for cancer and can arrest the cell division and stops cell proliferation very effectively (Fig. 6).

\section{Docking studies}

From the PatchDock results, the potent action of the drug toward the drug targets was confirmed. About four models were designed using SWISS model for each target. Of all the 8, only one target was selected, for which the patch dock score was high. The scores of model HUR and model HIFA were 4872 and 4716, respectively (Figs. 7 and 8). These two seems to be better fit than the other models.

\section{CONCLUSION}

Based on the significant findings from this work, it was confirmed that the drug was as potent as colchicines on the HeLa cell lines. Although the drug was being used in the clinical settings, no data were reported of its molecular validation. The two drug targets in the present study also confirm their possible role as anticancer drug targets which can be studied further. Even from in silico studies, it was found of the possible role of the receptors as novel drug targets and likely the drug Docetaxel might act on them.

\section{AUTHORS' CONTRIBUTIONS}

The first author (Salam) initiated and conducted the research and prepared the methods and results in the manuscript. The second author (Sudhakar) guided the first author in laboratory protocols and execution

\section{CONFLICTS OF INTEREST}

The authors declare that they have no conflicts of interest.

\section{REFERENCES}

1. Yang SH, Lu MC, Chien CM, Tsai CH, Lu YJ, Hour TC, et al. Induction of apoptosis in human leukemia K562 cells by cardiotoxin III. Life Sci 2005;76:2513-22.

2. Gao F, Li H, Chen YD, Yu XN, Wang R, Chen XL, et al. Upregulation of PTEN involved in scorpion venom-induced apoptosis in a lymphoma cell line. Leuk Lymphoma 2009;50:633-41.

3. Varinska L, Mirossay L, Mojzisova G, Mojzis J. Antiangogenic effect of selected phytochemicals. Pharmazie 2010;65:57-63.

4. Masuda S, Araki S, Yamamoto T, Kaji K, Hayashi H. Purification of a vascular apoptosis-inducing factor from hemorrhagic snake venom. Biochem Biophys Res Commun 1997;235:59-63.

5. Farokhzad OC, Langer R. Nanomedicine: Developing smarter therapeutic and diagnostic modalities. Adv Drug Deliv Rev 2006;58:1456-9.

6. Liu Y, Miyoshi H, Nakamura M. Nanomedicine for drug delivery and imaging: A promising avenue for cancer therapy and diagnosis using targeted functional nanoparticles. Int J Cancer 2007;120:2527-37.

7. Kawashima Y, Handa T, Kasai A, Takenaka H, Lin SY, Ando Y, et al. Novel method for the preparation of controlled-release theophylline granules coated with a polyelectrolyte complex of sodium polyphosphate-chitosan. J Pharm Sci 1985;74:264-8.

8. Freshney RI. Culture of Animal Cells: A manual of Basic Technique and Specialized Applications. $6^{\text {th }}$ ed. New York: Wiley-Liss; 2010. p. 187-206.

9. Hassan SB, Gali-Muhtasib H, Göransson H, Larsson R. Alpha terpineol: A potential anticancer agent which acts through suppressing NF-kappaB signalling. Anticancer Res 2010;30:1911-9.

10. Ribble D, Goldstein NB, Norris DA, Shellman YG. A simple technique for quantifying apoptosis in 96-well plates. BMC Biotechnol 2005;5:1-7.

11. Amatori S, Mazzoni L, Alvarez-Suarez JM, Giampieri F, Gasparrini M, Forbes-Hernandez TY, et al. Polyphenol-rich strawberry extract (PRSE) shows in vitro and in vivo biological activity against invasive breast cancer cells. Sci Rep 2016;6:30917.

12. Amatori S, Ballarini M, Faversani A, Belloni E, Fusar F, Bosari S, et al. PAT-chIP coupled with laser microdissection allows the study of chromatin in selected cell populations from paraffin-embedded patient samples. Epigenetics Chromatin 2014;7:18

13. Guerzoni C, Amatori S, Giorgi L, Manara MC, Landuzzi L, Lollini PL, et al. An aza-macrocycle containing maltolic side-arms (maltonis) as potential drug against human pediatric sarcomas. BMC Cancer 2014;14:137.

14. Rippo MR, Villanova F, Tomassoni Ardori F, Graciotti L, Amatori S, Manzotti S, et al. Dexamethasone affects fas- and serum deprivationinduced cell death of human osteoblastic cells through survivin regulation. Int J Immunopathol Pharmacol 2010;23:1153-65.

15. Sood S, Srinivasan R. Alterations in gene promoter methylation and transcript expression induced by cisplatin in comparison to 5-azacytidine in heLa and siHa cervical cancer cell lines. Mol Cell Biochem 2015;404:181-91

16. Sharma S, Kumar V. In vitro cytotoxicity effect on mef-7 cell line of co-encapsulated artesunate and curcumin liposome. Int J Pharm Pharm Sci 2017;9:123-8.

17. Maldonado V, Meléndez-Zajgla J, Ortega A. Modulation of NF-kappa B, and bcl-2 in apoptosis induced by cisplatin in heLa cells. Mutat Res 1997:381:67-75.

18. Sudhakar M. Chandrashekhar GR, Uppalapati S, Giridhar M, Nishitha A. Effect of wheat grass extracts (Triticum aestivum) on wound healing related proteins (syndecan 4 and tissue transglutaminase). World J Pharm Pharm Sci 2016;5:1040-54.

19. Golsteyn RM. Cdk1 and cdk2 complexes (cyclin dependent kinases) in apoptosis: A role beyond the cell cycle. Cancer Lett 2005;217:129-38.

20. Kaur M, Mandair R, Agarwal R, Agarwal C. Grape seed extract induces cell cycle arrest and apoptosis in human colon carcinoma cells. Nutr Cancer 2008;60 Suppl 1:2-11.

21. Danpure CJ. Lactate dehydrogenase and cell injury. Cell Biochem Funct $1984: 2: 144-8$

22. Sawant DV, Desai MM, Patil RS, Pawar SH. Evolution of nanotech assisted per diagnosis of Mycobacterium tuberculosis Aand its assessment with conventional methods. Int $\mathrm{J}$ Pharm Pharm Sci 2018;10:133-7. 